\title{
НЕОБХОДИМЫЙ ЧЕЛОВЕК (к 70-летию со дня рождения Ю.А. Мотова)
}

\section{(C) 2019 г. А.Е. Рогожинский}

В предложенной публикации автор приводит некоторые биографические данные о казахстанском археологе Ю.А. Мотове. Сведения о научном творчестве и жизни Юрия Аркадьевича изложены через призму личных впечатлений о встречах и совместной работе. Подчеркивается преданность археолога избранному делу, честность, ответственность, даже самоотверженность. В публикации присутствуют воспоминания о раскопках курганов могильника Шубарат, проявивших характер Ю.А. Мотова. Все действия, направленные на спасение аварийных памятников археологии, показывают Ю.А. Мотова, прежде всего, как гражданина и ученого.

Ключевые слова: археология, Ю.А. Мотов, памятник, курган, наука, ученый

«Дорогой наш Юрий Аркадьевич!..» - именно такими сердечными словами хотелось бы начать речь к юбилейной дате достойного человека - Юрия Аркадьевича Мотова (19492016) - профессионального археолога, исследователя многих знаковых памятников древности и средневековья Казахстана, бескорыстного Хранителя Древностей, но главное добровольного наставника молодых, кроме всего прочего служившего для нас образцом честности и добропорядочности - этаким символом человека правды и средневекового рыцарства. На таких людях - трудолюбивых, скромных и нечестолюбивых - поистине мир держится, потому что их присутствие в жизни порой кажется для окружающих незаметным, но отсутствие сразу заставляет понять, что этот человек был необходимым на земле...
Он происходил из трудовой крестьянской семьи, однако с малых лет судьба его оказалась связанной с замечательными древностями, коими богаты окрестности родного села у берегов священного озера Бийликуль недалеко от нынешнего Тараза. Здесь он в юности был свидетелем случайного открытия ныне знаменитой «Бийликульской личины», - к этой истории Юрий Аркадьевич вернется в одной из последних своих работ - здесь же им будет исследован размытый водами озера могильник Бийликуль, который стал вторым после Таутары профессионально изученным памятником бронзового века на юге Казахстана. Быть может, от этих «случайных» открытий гибнущих на наших глазах памятников древней истории берет начало его самоотверженная борьба за спасение культурного наследия, которая фактически 


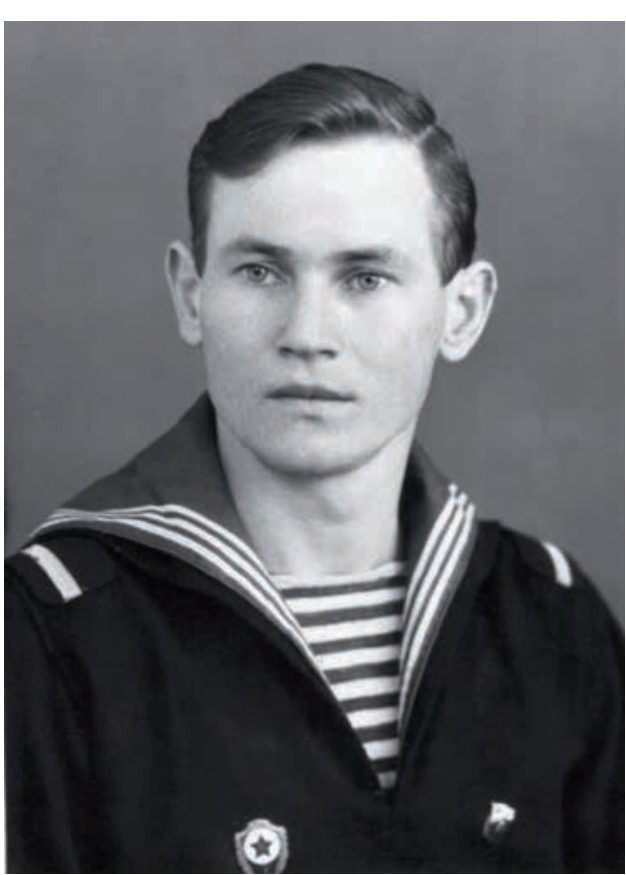

Юрий Аркадьевич Мотов в дни службь в Советской армии. Фото из семейного архива Ю.А. Мотова

Yuri A. Motov in the Soviet army. Photos from the family archive of Yu.A. Motov

стала главным содержанием всей жизни Ю.А. Мотова - гражданина и ученого.

Чувство персональной ответственности за судьбу каждого археологического памятника - будь то невзрачный черепок, каких тысячи лежат под ногами, или разрушаемые новостройками древний могильник и средневековое поселение - как будто изначально жило в нем и руководило поступками. Где бы он ни трудился, он всегда оставался Хранителем Древностей, и в этой своей главной ипостаси Юрий Аркадьевич как нигде чувствовал себя на своем месте, будучи заведующим отделом археологии Центрального музея Казахстана. Этот сравнительно значимый пост предоставлял ему некоторые административные полномочия для осуществления собственной высо- кой «миссии» Хранителя, и это позволяло ему временами одерживать маленькие победы - организовывать спасательные работы на курганных некрополях, ушедших под нож тракторов, или вызволять за деньги бесценные предметы сакского художественного литья. Но и тогда бывало, исчерпав возможности административного ресурса, и все же не достигнув благой цели, он принимал единственно правильное для себя решение и вступал в единоборство с «объективными обстоятельствами» во имя спасения обреченных на уничтожение памятников. Так случилось с огромным курганным полем возле Шамалгана, на месте которого в конце 1980-х возник животноводческий комплекс, а затем - с группой разновременных поселений и могильников в предгорьях Майбулака на окраине п. Фабричный... Взяв отпуск без содержания или выписав персональную командировку для проведения аварийных раскопок, он ехал к месту спасательных работ и один на один вступал в сражение... нет, не с ветряными мельницами, а с тракторами, ревущими своими многосильными моторами, да с экскаваторами, вычерпывавшими огромными ковшами курганные остатки, чтобы возвести на их месте железобетонные опоры гигантского коровника...

Осенью 1986 г. мне довелось быть свидетелем «рыцарского турнира», в котором Ю.А. Мотов сражался за малые курганы некрополя Шубарат под Шамалганом. С кем сражался? На поле битвы - с железной техникой, уговаривая рабочих и бригадиров дать ему день-два для раскопок очередного кургана, вошедшего в план стройки. На поле жизни - с бездушием и цинизмом чиновников от науки и культуры, создавшим «объ- 
ективные обстоятельства», которые обрекли не исследованный памятник на полное уничтожение.

Условия «турнира» были просты и жестоки: сколько успеешь раскопать курганов снятого с учета памятника, столько и спасешь для науки и для будущих обладателей культурного достояния... Зрелище было чудовищное! Маленький и щуплый на вид человек ежедневно от зари до зари исполнял свой профессиональный и гражданский долг: не отступая ни на шаг от методики полевых исследований, «обдирал» лопатой дерн, зачищал и зарисовывал в масштабе каменные насыпи курганов диаметром 6-8 метров... Юрий Аркадьевич искренне сокрушался, что не хватает у него сил спасать курганы «царских» размеров - более 10 м в диаметре! Далее - вручную удалял насыпь и приступал к выборке каменной забутовки могильной ямы, достигавшей двухметровой глубины. Матросская сноровка - он служил три года матросом Северного флота, но так и не научился хорошо плавать, ибо морской устав запрещал водные ордалии для североморцев! - так вот, хорошая выучка матроса и природная крестьянская смекалка помогли ему внедрить целую серию уникальных приемов раскопочной техники, позволявшей одному человеку извлекать с большой глубины глыбы весом до 100 кг, а затем, соревнуясь на время с рычащей вокруг техникой, исключительно аккуратно и точно завершать расчистку, зарисовку и фотографирование древнего погребения... Он гордился своими рекордами: два дня на полное исследование и документирование одного кургана! Полагаю, он спас таким путем десятка два списанных с ведомственного баланса науки и культуры курганов могильника Шубарат, - надеюсь, когда-нибудь этот подвиг оценят новые поколения археологов.

Той осенью я дважды приезжал с друзьями-добровольцами на выходные дни на Шубарат, чтобы хоть чем-то помочь этому отчаянному смельчаку. Именно в те дни, увидев своими глазами, к каким поступкам должен быть готовым настоящий Хранитель Древностей, я пропел ему шутливо перефразированную песню Ю.Е. Алешковского: «Товарищ Мотов, Вы большой ученый - в археологии познали толк...». Он сердился, отнекивался в ответ: «Ну уж, ну уж! Это не про меня!», и мне стало понятно, что не корысти ради и не для тщеты славы, а во имя чего-то более значимого для людей живет на земле этот добрый и честный, дорогой нам человек - Юрий Аркадьевич Мотов.

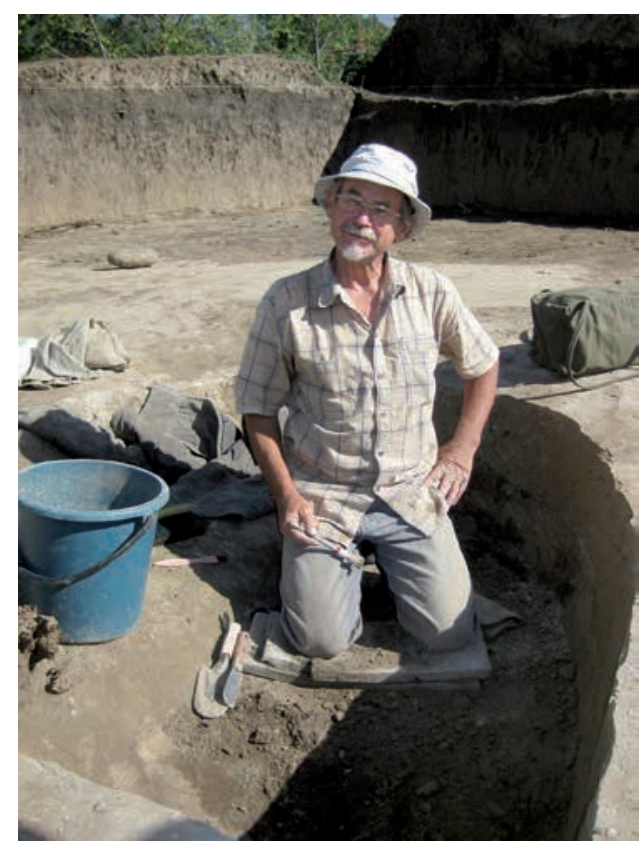

Ю.А. Мотов на Бутактьл.

Фото из семейного архива А.А. Горячева

Yu.A. Motov at the Butakty. Photos from the family archive A.A. Goryachev 


\section{Список основных публикаций Ю.А. Мотова*}

\section{Участие в книгах:}

1. Свод памятников истории и культуры Республики Казахстан. Жамбылская область. Алматы: РГП «НИПИ ПМК», 2002. Т. 2. 350 с., карты, ил. С. 207, 208-211, 216, 217 и др.

2. Свод памятников истории и культуры Республики Казахстан. Алматинская область. Алматы: Агентство «Маматай», 2009. 1320 с. С. 465-499, 527-591 и др.

3. Археологический комплекс Бутакты-I. Алматы: ТОО «KazBooKtrade», 2018. 264 с. Иллюстрации Института археологии им. А.Х. Маргулана, Археологической экспертизы (в соавт. с А.А. Горячевым).

\section{Публикации в рецензируемых изданиях:}

1. Новые петроглифы урочища Тамгалы // Вестник АН КазССР. 1979. № 8. С. 50-54 (в соавт. с А.Н. Марьяшевым, А.С. Ермолаевой).

2. Крепостные стены позднесредневекового Туркестана // Известия АН КазССР. Сер. обществ. наук. 1982. № 1. С. 40-46 (в соавт. с А.Н. Марьящевым).

3. К интерпретации изображений на парных пластинах из «Сибирской коллекции Петра I» // РА. 1999. № 3. С. 141-148.

4. Результаты исследований археологического комплекса Бутакты-1 на юговосточной окраине города Алматы в 2007 г. // Известия НАН РК. Сер. обществ. наук. 2008. № 1. С. 67-82 (в соавт. с А.А. Горячевым).

5. Результаты исследований археологического комплекса Бутакты-1 на юговосточной окраине города Алматы в 2008 г. // Известия НАН РК. Сер. обществ. наук. 2009. № 1. С. 13-24 (в соавт. с А.А. Горячевым).

6. Результаты исследований археологического комплекса Бутакты-1 на юговосточной окраине города Алматы в 2010 г. // Известия НАН РК. Сер. обществ. и гум. наук. 2012. № 3. С. 3-15 (в соавт. с А.А. Горячевымм).

\section{Участие в сборниках:}

1. Древности Бийликуля // Сибирь в древности. Новосибирск, 1979. С. 33-44.

2. Могильник Бийликуль - памятник ранней бронзы Южного Казахстана // Бронзовый век степной полосы Урало-Иртышского междуречья. Челябинск: Баш. ун-т, 1983. С. 153-158 (в соавт. с К.М. Карабаспаковой).

3. К истории государства огузских ябгу // Культура кочевников на рубеже веков (XIX-XX вв., XX-XXI вв.). Алматы, 1995. С. 31-38.

4. Нарты, «бори», шаманы (о мужчинах, пляшущих симд) // Жречество и шаманизм в скифскую эпоху: матер. междунар. конф. СПб., 1996. С. 32-36.

5. Героизация и обожествление вождей ранних кочевников Алтая (по материалам могильника Пазырык) // Военное искусство кочевников Центральной Азии и Казахстана (эпоха древности и средневековья). Алматы, 1998. С. 28-48.

6. К изучению идеологии раннесредневекового населения Алтая (по материалам могильника Кудыргэ) // История и археология Семиречья. Алматы, 2001. Вып. 2. C. $63-86$.

7. Раннесредневековые каменные оградки урочища Момбай-сазы // История и археология Семиречья. Алматы, 2001. Вып. 2. С. 142-149.

8. «Восхождение на Небо». К интерпретации погребального обряда Пазырыкской элиты по материалам первого кургана могильника Пазырык // История и археология Семиречья. Алматы, 2007. Вып. 3. С. 42-73. 
9. Могильник эпохи бронзы Каргалы-І // История и археология Семиречья. Алматы, 2007. Вып. 3. С. 80-87.

10. Свод памятников истории и культуры Алматинской области // Отчет об археологических исследованиях по программе «Культурное наследие». Алматы, 2007. С. 210-212 (в соавт. с А.Н. Марьямевым, А.А. Горячевым, С.А. Потаповым).

11. К вопросу о монгольских погребениях XIII-XIV вв. (по материалам некрополя Бозок) // Бозок в панораме средневековых культур Евразии: матер. междунар. полевого семинара. Астана: ЕНУ им. Л.Н. Гумилева, 2008. С. 56-65 (в соавт. с К.А. Акишевым Б.М. Хасеновой).

12. Петроглиф из урочища Ой-Джайляу // История и археология Семиречья. Алматы, 2011. Вып. 4. С. 158-164.

13. О так называемой «Бийликульской личине» // История и археология Семиречья. Алматы, 2011. Вып. 4. С. 165-172.

14. Керамический тагарский сосуд из погребения Ой-Джайляу // История и археология Семиречья. Алматы, 2011. Вып. 4. С. 192-194.

\section{Редакторская деятельность:}

1. История и археология Семиречья: сб. статей и публикаций. Алматы, 1999. Вып. 1.

2. История и археология Семиречья: сб. статей и публикаций. Алматы, 2001. Вып. 2.

3. История и археология Семиречья: сб. статей и публикаций. Алматы, 2007. Вып. 3.

4. История и археология Семиречья: сб. статей и публикаций. Алматы, 2011. Вып. 4.

\section{Литература о Ю.А. Мотове:}

1. Юрий Аркадьевич Мотов (1949-2016) // Известия НАН РК. Сер. обществ. и гум. наук. 2017. № 1 (311). С. 194.

2. Слово о Мотове... // История и археология Семиречья. Алматы, 2017. Вып. 5. С. 5-9. Предисловие редколлегии сборника.

3. Ермолаева А.С. Воспоминания о Юре // История и археология Семиречья. Алматы, 2017. Вып. 5. С. 10-11.

4. Усманова Э.Р. Один из последних казахстанских археологов-энциклопедистов, или три встречи с Юрием Мотовым // История и археология Семиречья. Алматы, 2017. Вып. 5. С. 12-13.

5. Хабдулина М.К. Ю.А. Мотов на городище Бозок // История и археология Семиречья. Алматы, 2017. Вып. 5. С. 14-16.

*Список основных публикаций Ю.А. Мотова составлен Г.С. Джумабековой и Г.А. Базарбаевой. Благодарим Ф.П. Григорьева, А.А. Горячева и Т.А. Егорову за помощь в подготовке списка.

\section{Сведения об авторе:}

Рогожинский Алексей Евгеньевич - кандидат исторических наук, ведущий научный сотрудник, Институт археологии им. А.Х. Маргулана (г. Алматы, Казахстан); alexeyro@hotmail.com 


\section{ҚАЖЕТТІ АДАМ \\ (Ю.А. Мотовтың туылғанына 70 жылдығына орай)}

\section{А.Е. Рогожинский}

Беріліп отырған мақалада автор қазақстандық археолог Ю.А. Мотов туралы кейбір ғұмырнамалық мәліметтер келтіреді. Юрий Аркадьевичтің ғылыми шығармашылығы мен өмірі туралы мәліметтер әріптестің кездесулері мен бірлескен жұмыс барысында алған әсерлері негізінде жазылған. Археологтың өзінің таңдап алған ісіне шын берілгендігі, адалдығы, жауапкершілігі, тіпті жанкештілігі де ашып айтылады. Мақалада Ю.А. Мотовтың мінезін аша түскен Шұбарат қорым қорғандарын қазу кезіндегі естеліктер де берілген. Апаттық жағдайдағы археологиялық ескерткіштерді құтақаруға бағытталған барлық іс-әрекеттер, ең алдымен, Ю.А. Мотовтың азаматтығы мен ғалымдығын танытады.

Түйін сөздер: археология, Ю.А. Мотов, ескерткіш, қорған, ғылым, ғалым

\section{IMPORTANT PERSON \\ (to the $\mathbf{7 0}^{\text {th }}$ anniversary of the birth of Yu.A. Motov)}

\section{A.E. Rogozhinskiy}

In the proposed publication, the author cites some biographical data of Kazakhstan archaeologist Yu.A. Motov. Information about scientific creativity and life of Yuri A. is presented through the prism of personal impressions of meetings and joint work with the colleague. The archaeologist's professional commitment, honesty, responsibility, even dedication is emphasized. The publication contains memories about the excavations of Shubarat gravemound, which showed the character of Yu.A. Motov. All actions aimed at saving emergency archaeological sites show Yu.A. Motov, above all, as the citizen and the scientist.

Keywords: archaeology, Yu.A. Motov, site, barrow, science, scientist

\section{About the Author:}

Rogozhinskiy Alexey E. Candidate of Historical Sciences, Leading Researcher, A.Kh. Margulan Archeology Institute, Almaty, Kazakhstan; alexeyro@hotmail.com 